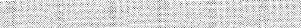 \\ 激しい下痢を呈した家族性アミロイドポリ \\ ニューロパシー (FAP) 患者に対する人工肛門 \\ の効果
}

\section{症例報告}

$\begin{array}{llll}\text { 堂坂 朗弘* } & \text { 安東由喜雄 } & \text { 田島 和周 } \\ \text { 中 由 由 } & \text { 坂下直実 } \text { 内野 誠 } \\ \text { 安藤正幸 } & & & \end{array}$

Key words : 家族性アミロイドポリニューロパシー (familial amyloidotic polyneuropathy), 人工肛門 (intestinal stoma), 下痢 (diarrhea)

リハ医学 $32: 193-195,1995$

\section{はじめに}

家族性アミロイドポリニューロパシー (FAP) タイ プI 患者は感覚優位のポリニューロパシーに加え， 種々の自律神経障害を呈する ${ }^{1 \sim 4)}$ ，とりわけ，発病初期 からみられる水様性の激しい下痢は本症患者の日常生 活に多大な制約を強い，るいそうの原因ともなる ${ }^{5,6)}$.

FAP 患者にみられる下痢は種々の薬剤投与では対処 しがたいことも多いことから ${ }^{4)}$ FAP 患者の多いス ウェーデン7では人工肛門を造設し対応してきてい る. 大腸の悪性腫瘍に伴う人工肛門の造設は，著しい 技術的進歩がみられるが ${ }^{8,9)}$, 脊髄損傷患者の裖瘡の管 理目的や激しい自律神経障害による下痢等を呈する場 合に人工肛門は一般化には至っていないのが現状であ る。われわれは激しい下痢を繰返し，日中活動時や夜 間就寝時に便失禁をきたしていた 38 歳, 男性の FAP 患者に人工肛門造設を試みた。

\section{症 例}

38 歳, 男性. 高校卒業後, 会社事務をしていたが, 26 歳頃より下痢, 食欲不振, 陰萎が出現. 29 歳時, 神 経生検にて FAP と診断された。 33 歳頃より，尿失禁 が頻発するため, 膀胱内カテーテルを留置した。1993
年 1 月 26 日, 歩行障害, 四肢筋力低下に対するリハビ リテーションを施行し, 高カロリー輸液などの栄養管 理目的にて当科に入院した。退院時, 体重は約 $2 \mathrm{~kg}$ 増 加するとともに本疾患に伴う進行性の筋力低下, 筋萎 縮の増悪はみられなかった。また, 本りハビリテーショ ンにより退院後日常生活の活動性の上昇がみられた。 退院後は生活保護を受け，一人暮らしのまま荒尾市民 病院, 国立福岡中央病院外来にて経過観察されていた. 同年， 6 月頃より下痢がひどくなり，夜間就寝中に便 失禁をするようになったため，本人に人工肛門の造設 術について説明したところ，本人の希望が強く，1994 年 1 月 19 日, 人工肛門造設術目的にて当科 2 回目の入 院となった. 入院時の理学的および神経学的所見を表 に示す，既往歷に特記すべきことなく，家族歴として は母が FAP で死亡している。

1994 年 2 月 17 日に二孔式にて人工肛門造設術を施 行した。術後の経過は尿路感染症を起こしたほかはほ ぼ順調であり, 1994 年 3 月 19 日退院となった。患者は 依然一人暮らしであったが，外出も可能となり日常生 活の行動範囲が広がった。また，下痢による寝具の污 染を心配することなく，夜間の良眠が得られるように なった。 
1) 理学所見

脈拍：72/分, 整, 血圧：160/110 mmHg（臥位) $\rightarrow 124 / 84 \mathrm{mmHg}$ (立位), 体温 : $36.1^{\circ} \mathrm{C}$,

身長：173 cm, 体重： $45 \mathrm{~kg}$, 標準体重：31.5\%のやせ

腹部：ぜん動音の亢進

\section{2 ) 神経学的所見}

意識 : 清明, 高次脳機能 : 正常

(A) 脳神経 :

III：瞳孔：脱円（楕円形）左右とも直径 $3 \mathrm{~mm}$ 対光反射 : 直接, 間接ともに (-)

輻輳反射：正常

III, IV, VI : 正常

$V$ : 咬筋 : (rt.) 5 (lt.) 5, 顔面感覚 : n. p.

VII : 眼輪筋 : (rt.) 4- (It.) 4-

口輪筋 : (rt.) 5 - (It.) 5 -

VIII : Weber test : midline

Rinne test : 左右とも $(+)$

IX, X, XII : 正常

$\mathrm{XI}$ ：胸鎖乳突筋：(rt.) 5- (It.) 5僧帽筋：(rt.) 5 (It.) 5

(B) 頸部：後屈にて運動痛 $(+)$

(C) 運動神経系：上肢で筋トーヌス低下, MMT $\rightarrow$ 図 遠位筋優位に筋萎縮を認める

(D) Coordination : 筋力低下のため slow decomposition (-) dysmetria ( - )

(E) 感覚神経系 : 頸以下に温覚の低下, 肋骨弓下の痛

(F) 起立：不可 覚の低下, 腸骨稜以下の触覚の低下

(G) 深部腱反射： $\rightarrow$ 図, 病的反射なし

(H) 自律神経系：膀胱内カテーテル留置 便失禁 $(+)$

起立性低血圧 $(+)$

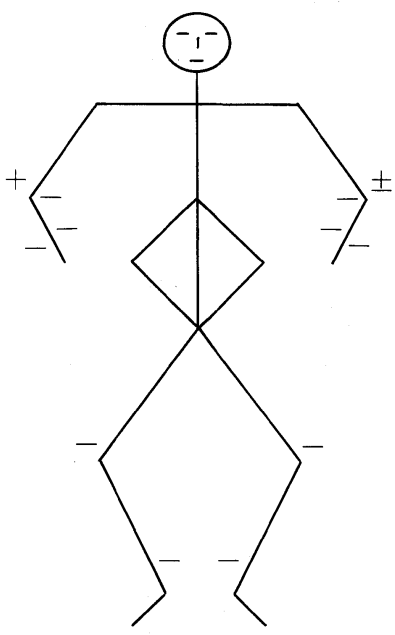

\begin{tabular}{|c|c|c|}
\hline 筋力 (右) & 筋 肉 & 筋力 (左) \\
\hline $4+$ & 大胸筋 & $4+$ \\
\hline 5 & 三角筋 & 5 \\
\hline $5-$ & 二頭筋 & $5-$ \\
\hline $5-$ & 三頭筋 & $5-$ \\
\hline $3-$ & 手根伸 & $3-$ \\
\hline $3+$ & 手根屈 & $3+$ \\
\hline $2+$ & 指 伸 & $2+$ \\
\hline $2-$ & 指 屈 & $3-$ \\
\hline 1 & 骨間筋 & 1 \\
\hline $3+$ & 腸腰筋 & $3+$ \\
\hline $3+$ & 股関節内転 & $3+$ \\
\hline $4-$ & 股関節外転 & $4-$ \\
\hline $3+$ & 大腿四頭筋 & $3+$ \\
\hline $3+$ & 大腿屈筋 & $3+$ \\
\hline $2-$ & 前脛骨筋 & $2-$ \\
\hline $2+$ & 下腿三頭筋 & $2+$ \\
\hline
\end{tabular}

\section{考 察}

本患者は術前, 激しい下痢が日常生活に制約を与え, 食物摂取不良からくる栄養状態の悪化も招いていた。 今回，人工肛門造設術により，自覚的に (1)トイレに長 時間座っていなくて済む，(2)夜間の便失禁に対して気 を使わなくて済む，(3)行動範囲がかなり広くなった， (4) 食物捸取にある程度制約を加えなくて済む，などの 利点が得られた．患者の握力が低下していたことから 污物処理が問題となったが，タッパウエア式の人工肛 門を用いることで解決した. FAP に対する人工肛門造
設術は，本邦においては未だ報告がないが，本患者の 術後の経過は極めて順調であり，術後の尿路感染症を 除くと極めて有効な下痢に対する対症療法であったと 考えられる。今後 FAP に限らず，激しい下痢をきた す内科的疾患においても本処置は一考するに值すると 考えられる.

人工肛門造設術の乱用は慎むべきであるが，悪性腫 瘍や腸管の器質的障害に伴う必然的人工肛門の造設 時 ${ }^{7,8)}$ と違い，手術手技も簡単であり時間も短い。 ある 程度進行した FAP 患者に対してこのような新しい治 療を取り入れていくことは，患者の QOL を向上する うえで極めて重要であると考えられた。 


\section{文 献}

1）荒木淑郎：アミロイドーシスとアミロイドニューロパ チー。星和書店, 東京, 1985 .

2) Araki S: Type I familial amyloidotic polyneuropathy (Japanese type). Brain Dev $6: 128-133$, 1984.

3）荒木淑郎：教育講演：家族性アミロイドニューロパ チーの臨床と deoxyribonucleic acid (DNA) 診断法. 日内会誌 76：998-1002，1987.

4) Ando Y, Shimoda O, Kano T, Araki S : Role of autonomic nerve functions in patients with familial amyloidotic polyneuropathy as analyzed by laser Doppler flowmetry, capsule hydrograph and cardiographic R-R interval. Muscle Nerve 15:507-512, 1992.

5) Ando $Y$, Nakagawa $T$, Ikegawa $S$, Hirota $M$, et al : Disturbed metabolism of glucose and related hormones in familial amyloidotic polyneuropathy : hypersensitivities of the autonomic nervous system and therapeutic prevention. J Auto Nerv Syst $35: 63-70,1991$.

6）安東由喜雄, 荒木淑郎, 安藤正幸: Transthyretin と 家族性アミロイドポリニューロパシー (FAP). 日内会 誌 $82: 1420-1423,1993$.

7) Hofer P-A, Andersson R : Postmortem findings in primary familial amyloidosis with polyneuropathy. Acta Path Microbiol Scand 83: 309-322, 1975.

8) Herschorn S, Thijssen AJ, Radomski SB : Experience with the hemi-Kock ileocystoplasty with a continent abdominal stoma. J Urol 149 : 998-1001, 1993.

9) Burgers JK, Quinlan DM, Brendler CB : Improved technique for creation of ideal conduit stoma. J Urol 144 : 1188-1190, 1990.

\title{
Intestinal Stoma for a Patient with Familial Amyloidotic Polyneuropathy Showing Severe Diarrhea
}

by

\author{
Akihiro Dosaka, M.D., Yukio Ando, M.D., Kazuhiro Tashima, M.D., \\ Yoshiya Tanaka, M. D., Naomi Sakashita, M. D., Makoto Uchino, M.D. \\ and Masayuki ANDo, M.D. \\ from
}

The First Department of Internal Medicine, Kumamoto University School of Medicine

(Jpn J Rehabil Med $32:$ 193-195, 1995)

A 38-year-old male patient with familial amyloidotic polyneuropathy underwent the operation for making the intestinal stoma because of his severe watery diarrhea. After the operation, his new colon function was normal without any particular troubles. He did not have to pay much attention for the diarrhea especially at night. This therapy may be very beneficial for him because he had been restricted his daily life by severe diarrhea. 